\title{
Analisis Hubungan Konstruksi Sumur Gali dan Sanitasi Lingkungan Terhadap Jumlah Bakteri Coliform Dalam Air Sumur Gali (Studi Kasus: Desa PAL IX, Kecamatan Sungai Kakap)
}

\author{
Utin Yeni Syafarida*, Dian Rahayu Jati*, Aini Sulastri \\ Jurusan Teknik Lingkungan, Fakultas Teknik, Universitas Tanjungpura, Jl. Prof. Dr. H. Hadari Nawawi, Pontianak 78124 , \\ Kalimantan Barat, Indonesia.
}

\begin{abstract}
ABSTRAK
Desa Pal IX merupakan wilayah yang terletak di Kecamatan Sungai Kakap yang masih banyak menggunakan sumur gali untuk memenuhi kebutuhan sehari-hari. Namun masih banyak sumur gali yang belum memenuhi persyaratan konstruksi dan sanitasi sesuai dengan SNI 03-2916-2992. Menurut data WHO 2013, diare merupakan satu diantara jenis penyakit yang dapat disebabkan akibat mengkonsumsi air yang telah tercemar oleh bakteri Coliform. Tujuan dari penelitian ini adalah menganalisis kondisi bakteriologis air sumur gali berdasarkan Permenkes RI No.32 Tahun 2017, hubungan konstruksi sumur gali dan sanitasi lingkungan terhadap jumlah bakteri Coliform dalam air sumur gali. Penelitian ini menggunakan metode observasi dan metode MPN dengan sampel penelitian sebanyak 10 sumur gali. Berdasarkan penelitian yang telah dilakukan, diketahui bahwa 8 dari 10 sampel tidak memenuhi syarat jumlah Coliform. Berdasarkan hasil analisis statistik, didapatkan bahwa ada hubungan antara konstruksi sumur dan sanitasi lingkungan gali terhadap kandungan bakteri Coliform yang ditandai dengan nilai $\mathrm{P}<0,05$. Hubungan sanitasi lingkungan terhadap kandungan bakteri Coliform adalah semakin dekat jarak sumur gali dengan sumber pencemaran, maka semakin tinggi kemungkinan kandungan bakteri Coliform yang terkandung dalam sumur gali. Hubungan konstruksi sumur gali terhadap bakteri Coliform adalah semakin buruk konstruksi sumur gali, maka kandungan bakteri Coliform di dalam air sumur gali akan semakin tinggi. Secara keseluruhan tidak ada sumur gali yang memenuhi persyaratan bakteriologis dan kondisi lingkungan yang terdapat di Desa Pal IX Kecamatan Sungai Kakap Kabupaten Kubu Raya.
\end{abstract}

Kata Kunci: Bakteri Coliform, Konstruksi Sumur, Sanitasi Lingkungan, Sumur Gali.

\begin{abstract}
Pal IX Village is an area located in Sungai Kakap District which still uses many dug wells to meet their daily needs. However, there are still many dug wells that do not meet the construction and sanitation requirements in accordance with SNI 03-29162992. According to 2013 WHO data, diarrhea is one of the types of diseases that can be caused by consuming water that has been contaminated with Coliform bacteria. The purpose of this study was to analyze the bacteriological condition of dug well water according to the quality Standars regulation of the Minister of Health of the Republic of Indonesia No. 32 year 2017, the relationship of dug well construction and environmental sanitation on the number of Coliform bacteria in dug well water. This study used the observation method and the MPN method with a sample of 10 dug wells. Based on the research that has been done, it is known that $80 \%$ of the samples do not meet the requirements for the number of Coliforms. Based on the results of statistical analysis, it was found that there was a relationship between well construction and environmental sanitation on the content of Coliform bacteria which was indicated by a $\mathrm{P}$ value $<0.05$. The relationship between environmental sanitation and Coliform bacteria content is that the closer the dug well is to the source of pollution, the higher the possibility of Coliform bacteria content contained in the dug well. The relationship between dug well construction and Coliform bacteria is that the worse the dug well construction, the higher the Coliform bacteria content in the dug well water. Overall, there are no dug wells that meet the bacteriological requirements and environmental conditions in Pal IX village, Sungai Kakap district, Kubu Raya regency.
\end{abstract}

Keywords: Coliform Bacteria, Dug Wells, Environmental Sanitation, Well Construction.

Citation: Syafarida, U. Y.., Jati, D. R., dan Sulastri, A. (2021). Analisis Hubungan Konstruksi Sumur Gali Dan Sanitasi Lingkungan Terhadap Jumlah Bakteri Coliform Dalam Air Sumur Gali (Studi Kasus: Desa Pal IX, Kecamatan Sungai Kakap), Jurnal Ilmu Lingkungan, 20(3), 437-444, doi:10.14710/jil.20.3.437-444

\section{Pendahuluan}

Air bersih merupakan salah satu kebutuhan utama bagi manusia, sehingga ketersediaannya sangat penting karena dapat menjadi salah satu faktor penentu kesejahteraan manusia. Penyediaan air bersih yang banyak digunakan untuk memenuhi kebutuhan hidup salah satunya adalah air tanah. Air tanah yang banyak dimanfaatkan oleh masyarakat adalah sumur gali. Masyarakat yang tinggal di wilayah pedesaan

\footnotetext{
*Penulis korespondensi: utinyenif@gmail.com
} 
masih banyak yang menggunakan sumur gali untuk memenuhi kegiatan sehari- hari dikarenakan terbatasnya akses PDAM (Perusahaan Daerah Air Minum) yang masuk ke dalam desa.

Air sumur gali sangat mudah terkontaminasi oleh bakteri yang berasal dari limbah buangan ataupun kotoran manusia. Hal ini terjadi karena air sumur gali dapat berasal dari lapisan tanah yang dangkal, sehingga menyebabkan limbah ataupun sampah yang dibuang di atas permukaan akan merembes masuk ke dalam tanah dan mencemari air tanah. Menurut data WHO (World Health Organization) pada tahun 2013, diare penyebab nomor satu kematian balita di seluruh dunia. Menurut Hanan (2020), penyakit diare merupakan satu diantara jenis penyakit yang dapat disebabkan akibat mengkonsumsi air yang telah tercemar oleh bakteri Coliform.

Kondisi fisik sumber air bersih berpengaruh terhadap jumlah bakteri Coliform yang terdapat dalam air bersih yaitu semakin baik kondisi fisik sumber air bersih maka kandungan bakteriologis air sumur semakin sedikit (Radjak, 2013). Sebaliknya jika semakin buruk kondisi fisik sumber air bersih maka kandungan bakteriologis sumber air bersih akan semakin banyak. Pencemaran air sumur gali tidak hanya berasal dari keberadaan dan jumlah sumber pencemar tetapi juga dipengaruhi oleh kondisi konstruksi sumur gali itu sendiri yang meliputi dinding sumur bagian atas, dinding sumur bagian bawah, lantai sumur dan saluran pembuangan sesuai dengan SNI 032916-1992 tentang Spesifikasi Sumur Gali Untuk Air Bersih.

Desa Pal IX merupakan wilayah dengan kepadatan penduduk tertinggi yakni 541,96 jiwa/km2 di Kecamatan Sungai Kakap (BPS Kubu Raya, 2020). Meningkatnya jumlah penduduk di suatu daerah mampu menghasilkan jumlah sampah dan limbah dalam jumlah besar yang berbentuk senyawa organik dan anorganik yang dibuang ke lingkungan sehingga berpengaruh pada kualitas air tanah. Selain itu, diketahui pula berdasarkan data dari profil Desa Pal IX tahun 2020, dari 8.883 unit sarana air bersih yang digunakan oleh masyarakat, 2.459 unit diantaranya menggunakan sarana sumur gali untuk kebutuhan air sehari-hari. Air sumur gali tersebut dipergunakan sebagai sumber air bersih untuk keperluan domestik rumah tangga juga termasuk untuk air minum yang dimasak tanpa pengolahan khusus sebelumnya. Masyarakat yang kurang terjangkau oleh adanya penyediaan air bersih mempunyai risiko menderita diare lebih besar dibandingkan masyarakat yang mudah mendapatkan akses air bersih (Kemenkes, 2011). Sehingga perlu dikaji hubungan konstruksi sumur gali dan sanitasi lingkungan terhadap kualitas bakteriologis air sumur gali di Desa Pal IX, Kecamatan Sungai Kakap, Kabupaten Kubu Raya.

\section{Bahan dan Metode}

Penelitian ini dilakukan di Desa Pal IX, Kecamatan Sungai Kakap, Kabupaten Kubu Raya. Pengujian parameter bakteriologis air minum isi ulang dilakukan di Laboratorium Mikrobiologi Lingkungan, Fakultas Teknik, Universitas Tanjungpura. Waktu penelitian dilakukan pada bulan Mei - Juni 2021. Peralatan yang digunakan dalam penelitian ini adalah pipet volume, neraca analitik, spatula, erlenmeyer, bunsen, rak tabung reaksi, tabung durham, tabung reaksi, inkubator, autoklaf, botol sampel, plastik wrapping, mikropipet, blue tip, korek api, alat tulis, dan kamera. Bahan-bahan yang digunakan dalam penelitian ini adalah media Lactose Broth (LB), media Brillian Green Lactose Broth (BGLB), akuades, alkohol 70\% dan sampel air sumur gali yang telah diambil dari sumur gali di Desa Pal IX, Kecamatan Sungai Kakap.

Teknik sampling yang digunakan dalam penelitian ini adalah purpossive sampling. Pada teknik ini, pengambilan sampel anggota populasi dilakukan berdasarkan pertimbangan atau kriteria tertentu. Penentuan sampel pada penelitian ini dilakukan berdasarkan kriteria:

a. Sumur yang digunakan sebagai sampel penelitian berupa sumur yang aktif digunakan.

b. Air sumur masih digunakan sebagai sumber kebutuhan domestik rumah tangga seperti mandi, sikat gigi, cuci pakaian mencuci alat makan dan sebagainya. Bentuk konstruksi dan kondisi fisik sumur gali.

c. Keberadaan sanitasi lingkungan di sekitar sumur gali.

d. Pemilik sumur gali bersedia sumurnya untuk dijadikan sampel penelitian.

Berdasarkan kriteria tersebut, sampel pada penelitian ini berjumlah 10 sampel sumur gali yang terdapat di Desa Pal IX, Kecamatan Sungai Kakap sesuai dengan tujuan yang ingin dicapai didalam penelitian ini yakni perbedaan konstruksi dan jarak sanitasi lingkungan. Prosedur penelitian ini terdiri dari 3 tahapan, yaitu:

a. Pemeriksaan konstruksi sumur gali dan sanitasi lingkungan, dilakukan dengan pengamatan dan pengukuran menggunakan meteran dan lembar checklist yang diadopsi dari Formulir Inspeksi Sanitasi Lingkungan dalam Permenkes No. 416/MENKES/PER/IX/1990 tentang Syarat-syarat dan Pengawasan Kualitas Air terhadap kondisi fisik sumur gali yang meliputi tinggi dinding sumur, lebar bibir sumur, kondisi lantai sumur, jarak sumur gali terhadap septic tank, tempat pembuangan sampah dan saluran pembuangan air limbah (SPAL).

b. Pengambilan sampel dilakukan dengan cara pengambilan sampel sebanyak 10 sampel air pada masing-masing sumur gali. 


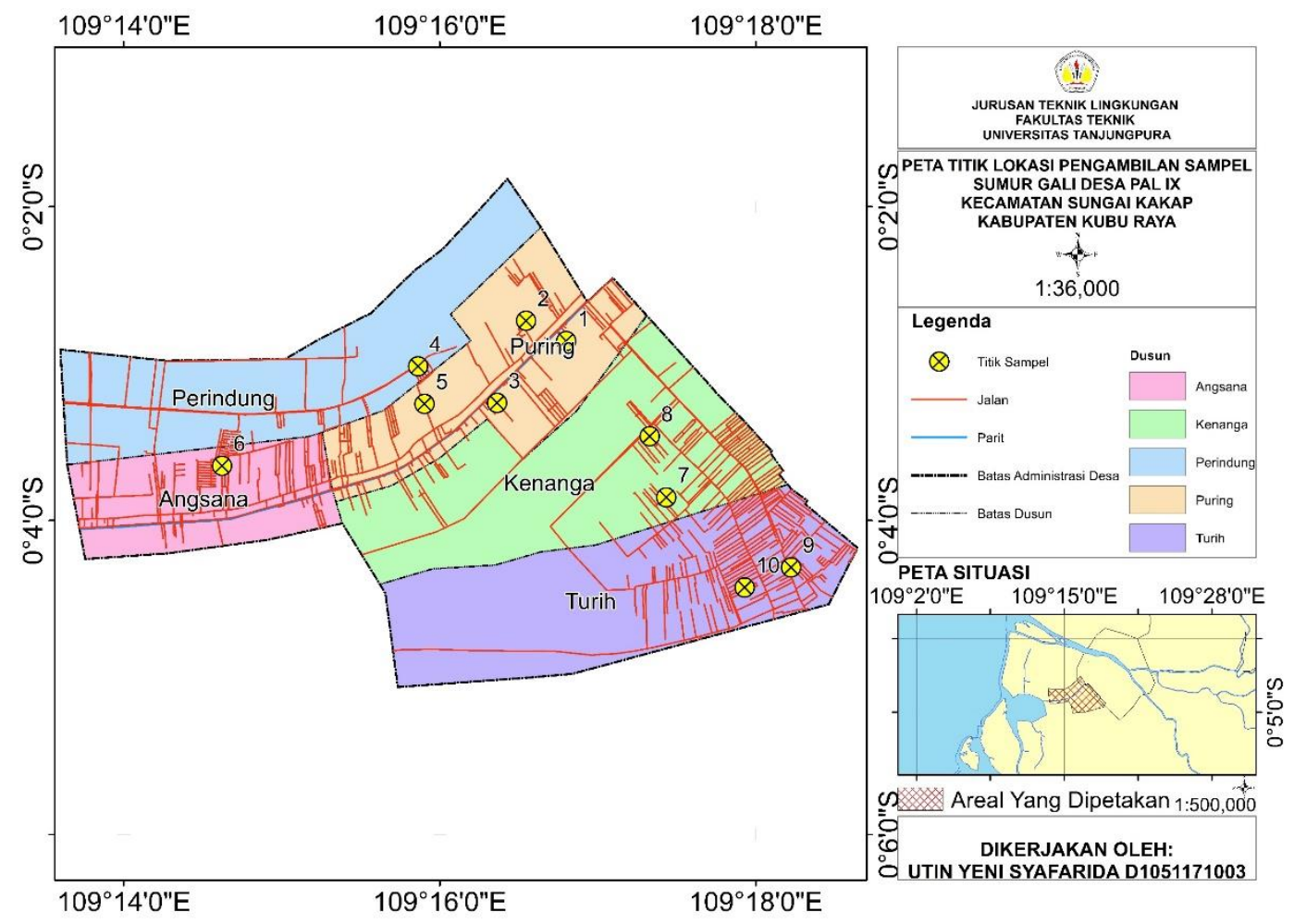

c. Uji bakteri Coliform dilakukan dengan menggunakan metode MPN. Terdapat 2 tahapan dalam uji bakteri Coliform yaitu uji pendahuluan yang menggunakan media Lactose Broth (LB) dan uji penegasan yang menggunakan media Brillian Green Lactose Broth (BGLB). Jumlah tabung yang positif dicocokkan dengan nilai pada tabel MPN untuk mengetahui jumlah bakteri Coliform pada air sampel yang diamati.

Teknik analisis data yang digunakan dalam penelitian ini adalah analisis statistik dengan analisis univariat dan bivariat. Hasil observasi yang diperoleh dianalisis berdasarkan SNI 03-2916-1992, sedangkan hasil pemeriksaan bakteri Coliform dibandingkan dengan Permenkes RI No.32 Tahun 2017, apakah hasil pemeriksaan bakteri Coliform masih memenuhi persyaratan atau tidak. Analisis univariat dilakukan untuk mendeskripsikan konstruksi sumur dan sanitasi lingkungan, serta bakteri jumlah bakteri Coliform yang terdapat dalam air sumur gali. Selanjutnya dilakukan analisis bivariat untuk mengetahui hubungan konstruksi dan sanitasi lingkungan dengan jumlah bakteri Coliform yang terdapat pada air sumur gali. Uji statistik yang digunakan adalah menggunakan uji Chi Square $\left(\chi^{2}\right)$.

\section{Hasil dan Pembahasan}

A. Kualitas Air Sumur Gali Berdasarkan Kandungan Bakteriologis di Desa Pal IX Kecamatan Sungai Kakap
Kandungan bakteri Coliform pada sampel air sumur gali dilakukan dengan menggunakan metode MPN (Most Probably Number). Uji ini dilakukan untuk mengetahui jumlah bakteri Coliform yang terkandung di dalam air sumur gali. Menurut Peraturan Menteri Kesehatan Republik Indonesia No. 32 Tahun 2017 tentang Standar Baku Mutu Kesehatan Lingkungan untuk Media Air untuk Keperluan Higiene Sanitasi Kolam Renang, Solus Per Aqua, dan Permandian Umum, jumlah bakteri Coliform yang diperbolehkan dalam air bersih adalah 50 MPN/100 ml sampel. Bakteri Coliform digunakan sebagai parameter bakteriologis kualitas air karena cukup mudah dideteksi dalam sampel air dan mudah dikualifikasi.

Tabel 1. Kandungan Bakteri Coliform dalam Air Sumur Gali

\begin{tabular}{cccc}
\multicolumn{4}{c}{ di Desa Pal IX Kecamatan Sungai Kakap } \\
\hline No. & $\begin{array}{c}\text { Titik } \\
\text { Sampel } \\
\text { Sumur } \\
\text { Gali }\end{array}$ & $\begin{array}{c}\text { Nilai MPN } \\
\text { (MPN/100 } \\
\text { ml) }\end{array}$ & $\begin{array}{c}\text { Standar Baku Mutu } \\
\text { (50 MPN/100 ml) }\end{array}$ \\
\hline 1 & SGL 1 & 280 & Tidak Memenuhi Syarat \\
\hline 2 & SGL 2 & 540 & Tidak Memenuhi Syarat \\
\hline 3 & SGL 3 & 170 & Tidak Memenuhi Syarat \\
\hline 4 & SGL 4 & 94 & Tidak Memenuhi Syarat \\
\hline 5 & SGL 5 & 119 & Tidak Memenuhi Syarat \\
\hline 6 & SGL 6 & 39 & Memenuhi Syarat \\
\hline 7 & SGL 7 & 180 & Tidak Memenuhi Syarat \\
\hline 8 & SGL 8 & 210 & Tidak Memenuhi Syarat \\
\hline 9 & SGL 9 & 430 & Tidak Memenuhi Syarat \\
\hline 10 & SGL 10 & 47 & Memenuhi Syarat \\
\hline
\end{tabular}

Sumber: Hasil Analisis, 2021 
Hasil uji laboratorium menunjukkan bahwa kandungan bakteri Coliform dalam air sumur gali memiliki rentang nilai $39-540 \mathrm{MPN} / \mathrm{ml}$ yang berarti air sumur gali tersebut telah tercemar oleh bakteri Coliform. Sampel air sumur gali pada sumur gali 2 memiliki nilai MPN tertinggi jika dibandingkan dengan sampel air sumur gali lainnya yaitu mencapai 540 MPN/100 ml sampel air. Nilai MPN yang cukup tinggi ini dapat disebabkan karena pada sumur gali 2 memiliki jarak yang dekat dengan sumber pencemar di sekitarnya seperti jarak terhadap septic tank, tempat pembuangan sampah, saluran pembuangan air limbah dan terdapat pencemar lain seperti kandang hewan yang dekat dengan sarana sumur gali. Selain itu, sumur gali 2 secara fisik tidak memenuhi syarat untuk konstruksi sumur gali. Sedangkan pada sampel air sumur gali 6 dan sumur gali 10 memiliki nilai MPN terendah jika dibandingkan dengan sampel air sumur gali lainnya yaitu 39 MPN/100 ml dan 47 MPN/100 ml sampel air. Hal ini dapat disebabkan oleh kondisi fisik atau konstruksi sumur gali yang cukup baik serta memiliki jarak yang cukup jauh dari sumber pencemaran yang menjadi risiko kontaminasi terhadap air sumur (Dayani, 2019).

B. Hubungan Konstruksi Sumur dan Sanitasi

Lingkungan terhadap Jumlah Bakteri Coliform

Sumur gali sebagai sumber air bersih harus ditunjang dengan syarat konstruksi untuk dibangunnya sebuah sumur gali, hal ini diperlukan agar kualitas air sumur gali aman sesuai aturan yang ditetapkan. Konstruksi sumur gali meliputi aspek dinding sumur gali, bibir sumur gali dan lantai sumur gali. Sanitasi lingkungan disekitar sarana sumur gali perlu diperhatikan untuk mencegah adanya kontaminasi terhadap air sumur. Menurut SNI 032916-1992 mengenai Spesifikasi Sumur Gali untuk Sumber Air Bersih, sanitasi lingkungan yang dapat menjadi sumber pencemar apabila jaraknya $<10$ meter adalah seperti septic tank, tempat pembuangan sampah dan saluran pembuangan air limbah (SPAL) (Herninda dkk, 2016). Sumur gali yang baik wajib memenuhi syarat konstruksi dan sanitasi sumur gali sesuai dengan SNI 03-2916-1992 Spesifikasi Sumur Gali untuk Air Bersih. Hasil analisis statistik terhadapat variabel pengamatan dapat dilihat pada Tabel 2 .

Tabel 2. menunjukkan hasil uji statistik chisquare yang diperoleh nilai $P$ value sebesar $0,016(\mathrm{p}$ value $<0,05$ ). Nilai $P$ value $<0,05$ yang menunjukkan ada hubungan antara jarak septic tank dengan kandungan bakteri Coliform di dalam air sumur gali di Desa Pal IX Kecamatan Sungai Kakap. Jarak septic tank dengan sumur gali yang tidak memenuhi syarat $(<10$ meter) dapat menjadi faktor adanya kandungan bakteri Coliform. Sumur yang memiliki kandungan Coliform memenuhi syarat kemungkinan septic tank yang ada dikeluarga tersebut berfungsi dengan baik serta konstruksi dari sumur gali sudah hampir memenuhi syarat meskipun tidak semua sumur mempunyai konstruksi yang memenuhi syarat (Achmad, 2020).

Adanya hubungan antara jarak septic tank terhadap kandungan bakteri Coliform dalam air sumur gali dapat disebabkan oleh jarak bangunan septic tank yang dekat dengan sarana sumur gali yang tidak kedap air. Menurut Stiffany (2018), hal ini dapat mempengaruhi laju infiltrasi sehingga mempengaruhi penyerapan bakteri.

Tabel 2. Hubungan Konstruksi dan Sanitasi Lingkungan Terhadap Jumlah Coliform

\begin{tabular}{|c|c|c|c|c|c|c|}
\hline \multirow[b]{2}{*}{ No. } & \multirow{2}{*}{\multicolumn{2}{|c|}{ Variabel Pengamatan }} & \multicolumn{3}{|c|}{ Kualitas Bakteriologis } & \multirow[b]{2}{*}{$\begin{array}{l}\text { Nilai p- } \\
\text { value }\end{array}$} \\
\hline & & & Memenuhi & $\begin{array}{c}\text { Tidak } \\
\text { Memenuhi }\end{array}$ & Jumlah & \\
\hline \multirow{2}{*}{1} & \multirow{2}{*}{ Dinding Sumur Gali } & Memenuhi Syarat & 2 & 1 & 3 & \multirow{2}{*}{0,016} \\
\hline & & Tidak Memenuhi Syarat & 0 & 7 & 7 & \\
\hline \multirow{2}{*}{2} & \multirow{2}{*}{ Bibir Sumur Gali } & Memenuhi Syarat & 2 & 1 & 3 & \multirow{2}{*}{0,016} \\
\hline & & Tidak Memenuhi Syarat & 0 & 7 & 7 & \\
\hline \multirow{2}{*}{3} & \multirow{2}{*}{ Lantai Sumur Gali } & Memenuhi Syarat & 1 & 0 & 1 & \multirow{2}{*}{0,035} \\
\hline & & Tidak Memenuhi Syarat & 1 & 8 & 9 & \\
\hline \multirow{2}{*}{4} & \multirow{2}{*}{ Jarak Septic Tank } & Memenuhi Syarat & 2 & 1 & 3 & \multirow{2}{*}{0,016} \\
\hline & & Tidak Memenuhi Syarat & 0 & 7 & 7 & \\
\hline \multirow{2}{*}{5} & \multirow{2}{*}{ Jarak TPS } & Memenuhi Syarat & 1 & 0 & 1 & \multirow{2}{*}{0,035} \\
\hline & & Tidak Memenuhi Syarat & 1 & 8 & 9 & \\
\hline 6 & Jarak SPAL & Memenuhi Syarat & 1 & 3 & 4 & 0,747 \\
\hline
\end{tabular}


Berdasarkan hasil uji statistik chi square, hubungan antara jarak tempat pembuangan sampah dan kandungan bakteri Coliform memiliki nilai P value sebesar 0,035 . Nilai $\mathrm{P}$ value $<0,05$ yang menunjukkan ada hubungan antara jarak tempat pembuangan sampah dengan kandungan bakteri Coliform di dalam air sumur gali di Desa Pal IX Kecamatan Sungai Kakap. Adanya hubungan antara jarak tempat pembuangan sampah dan kandungan bakteri Coliform di dalam sumur gali diasumsikan terjadi karena adanya pencemaran oleh air lindi ke dalam sumur gali. Air lindi merupakan cairan yang berasal dari limbah tempat pembuangan sampah yang banyak mengandung mikroorganisme dan air lindi akan mengalir dari tempat tinggi ke tempat yang lebih rendah. Sanitasi lingkungan yang buruk diantaranya sampah yang berserakan merupakan potensi timbulnya berbagai vektor penyakit (Puji, 2019). Keadaan seperti ini menjadi tempat sekaligus mempermudah perkembangbiakan bakteri.

Nilai P value untuk hubungan SPAL dan bakteri Coliform adalah sebesar 0,747 . Nilai $\mathrm{P}$ value $>0,05$ dalam hal ini hipotesis nol (Ho) pada penelitian ini diterima yang berarti menunjukkan tidak ada hubungan antara jarak saluran pembuangan air limbah (SPAL) dengan kandungan bakteri Coliform di dalam air sumur gali di Desa Pal IX Kecamatan Sungai Kakap. Tidak adanya hubungan antara jarak saluran pembuangan air limbah (SPAL) dengan kandungan bakteri Coliform di dalam air sumur gali di Desa Pal IX Kecamatan Sungai Kakap dapat terjadi karena konstruksi dari saluran pembuangan air limbah (SPAL) berupa got atau selokan yang digunakan untuk membuang atau mengumpulkan air buangan dari sisa aktivitas rumah tangga. Hasil pengamatan lainnya di lokasi penelitian menunjukkan bahwa beberapa saluran pembuangan air limbah terhadap sarana sumur gali dibuat dengan cukup baik sehingga tidak terjadi kebocoran dan penyerapan air limbah oleh tanah sekitar sumur. Hal ini sejalan dengan penelitian yang dilakukan Tattit (2011) yang menyatakan bahwa tidak ada hubungan yang bermakna statistik antara jarak saluran pembuangan air limbah (SPAL) dengan kandungan bakteri Coliform pada air sumur gali.

Adanya hubungan konstruksi dinding sumur gali dan kandungan bakteri Coliform di Desa Pal IX Kecamatan Sungai Kakap diasumsikan karena persepsi masyarakat yang menganggap bahwa sumur gali yang memiliki dinding terbuat dari cincin beton sudah aman dari pencemaran lingkungan sekitar. Namun, berdasarkan hasil observasi lapangan ditemukan celah atau retakan-retakan pada dinding beton dan masih banyak masyarakat yang menggunakan dinding sumur yang tidak mencapai atau kurang dari 3 meter. Menurut Sumantri (2010), air bersih sampai kedalaman 3 meter masih diperkirakan mengandung bakteri. Dinding sumur gali yang kokoh dan permanen memproteksi sumur gali dari bakteri-bakteri patogen maupun non- patogen yang ada dalam tanah.

Berdasarkan hasil uji statistik chi square, didapatkan nilai $\mathrm{P}$ value adalah sebesar 0,016 yang berarti ada hubungan antara konstruksi sumur gali ditinjau dari aspek bibir sumur gali terhadap kandungan bakteri gali dengan kandungan bakteri Coliform di dalam air sumur gali di Desa Pal IX Kecamatan Sungai Kakap. Adanya hubungan antara bibir sumur gali dengan kandungan bakteri Coliform disebabkan oleh mayoritas sumur gali yang dimiliki masyarakat di Desa Pal IX Kecamatan Sungai Kakap memiliki tinggi rata-rata kurang dari $70 \mathrm{~cm}$ dan bahkan ada yang tidak memiliki bibir sumur. Sumur gali yang memiliki bibir sumur tidak memenuhi syarat memberikan pengaruh terhadap penurunan kualitas air sumur gali yang dihasilkan.

Berdasarkan hasil uji statistik chi square, didapatkan nilai $\mathrm{P}$ value adalah sebesar 0,035 . Nilai $\mathrm{P}$ value $<0,05$ dengan demikian hipotesis nol (Ho) ditolak yang berarti ada hubungan antara kontruksi sumur gali ditinjau dari aspek lantai sumur gali terhadap kandungan bakteri Coliform di dalam air sumur gali di Desa Pal IX Kecamatan Sungai Kakap. Adanya hubungan antara lantai sumur gali dan kandungan bakteri Coliform dikarenakan fakta lapangan yang masih banyak ditemukan lantai sumur gali yang tidak kedap air bahkan ditemukan sumur gali beralaskan tanah atau tidak menggunakan lantai. Kondisi sarana sumur gali yang tidak memiliki lantai, adanya keretakan maupun genangan air di sekitar sumur gali dapat menyebabkan air buangan masuk dan merembes ke dalam sumur gali. Adanya genangan air di sekitar sarana sumur gali merupakan habitat bagi bakteri dengan didukung oleh adanya kandungan bahan organik dalam genangan air tersebut mengakibatkan bakteri tumbuh subur (Nashiroh, 2017). Keretakan lantai sumur gali atau lantai yang tidak memiliki lantai dijadikan jalan bagi bakteri untuk dapat masuk ke dalam sumur melalui perantara air (genangan air).

C. Penerapan Sumur Gali yang Tepat di Desa Pal IX Kecamatan Sungai Kakap

Berikut hasil analisis terhadap variabel pengamatan sumur gali di Desa Pal IX Kecamatan Sungai Kakap yang memenuhi syarat dan tidak memenuhi syarat diuraikan pada tabel 3 sebagai berikut. 
Tabel 3. Hasil Analisis Kandungan Bakteri Coliform, Sanitasi Lingkungan dan Konstruksi Sumur Gali

\begin{tabular}{llll}
\hline & & Variabel Pengamatan & \multicolumn{2}{c}{ Jumlah Sumur Gali } \\
\cline { 3 - 4 } No. & & $\begin{array}{c}\text { Tidak Memenuhi } \\
\text { Syarat }\end{array}$ & $\begin{array}{c}\text { Memenuhi } \\
\text { Syarat }\end{array}$ \\
\hline 1. & Bakteri Coliform & 8 & 2 \\
\hline 2. & Septic Tank & 7 & 3 \\
\hline 3. & Tempat Pembuangan Sampah & 9 & 1 \\
\hline 4. & Saluran Pembuangan Air Limbah (SPAL) & 6 & 4 \\
\hline 5. & Dinding Sumur Gali & 7 & 3 \\
\hline 6. & Bibir Sumur Gali & 7 & 3 \\
\hline 7. & Lantai Sumur Gali & 9 & 1 \\
\hline
\end{tabular}

Sumber: Hasil Analisis, 2021

Berdasarkan Tabel 3 hasil analisis dari pengamatan kandungan bakteri Coliform, sanitasi lingkungan dan konstruksi sumur gali yang telah dilakukan, keseluruhan sarana sumur gali yang dijadikan sampel tidak memenuhi SNI 03-2916-1992. Selain tidak memenuhi syarat dari aspek sanitasi lingkungan dan konstruksi sarana sumur gali, sebanyak 8 dari 10 sampel air sumur gali tidak memenuhi syarat kebutuhan air bersih sesuai dengan risiko pencemaran pada sarana air sumur gali di Desa Pal IX berdasarkan Permenkes No. 416/MENKES/PER/IX/1990 dapat dilihat pada tabel 4.

Peraturan Menteri Kesehatan No. 32 Tahun 2017 tentang Standar Baku Mutu Kesehatan Lingkungan untuk Media Air untuk Keperluan Higiene Sanitasi, Kolam Renang, Solus Per Aqua, dan Permandian Umum. Sehingga sumur gali yang dijadikan sampel dalam penelitian ini tidak ada yang mendukung untuk diterapkan di Desa Pal IX Kecamatan Sungai Kakap. Semakin banyak yang tidak memenuhi syarat maka semakin tinggi tingkat risiko pencemaran air, dimana semakin banyak kemungkinan bahan pencemar yang masuk ke dalam sarana sumur gali sehingga dapat menurunkan kualitas air sumur gali tersebut. Berikut merupakan hasil inspeksi tingkat resiko.

Berdasarkan tabel 4 hasil inspeksi tingkat risiko pencemaran sarana sumur gali yang terdapat di Desa Pal IX Kecamatan Sungai Kakap, sebanyak 8 sumur gali dengan kategori tinggi, 1 sumur gali dengan kategori sedang dan 1 sumur gali dengan kategori rendah. Tingkat risiko pencemaran tinggi di Desa Pal IX Kecamatan Sungai Kakap sebagian besar memiliki kondisi adanya sumber pencemar pada jarak $<10$ meter, adanya genangan air di sekitar sarana sumur gali, tidak mempunyai lantai semen sekitar sumur gali, bibir sumur gali tidak dibuat setinggi $70 \mathrm{~cm}$ dari permukaan tanah, dan dinding sumur gali yang dibuat dengan kedalaman < 3 meter. Tingkat risiko pencemaran sedang dikarenakan dari segi konstruksi sumur gali ada beberapa yang belum memenuhi syarat konstruksi sumur gali yaitu lantai sumur gali. Lantai sumur gali tidak dibuat menggunakan lantai semen dan kedap air, sehingga seaktu-waktu masih terdapat genangan air disekitar sumur yang dapat menjadi risiko kontaminasi (Angela dkk, 2012).

Tabel 4. Tingkat Risiko Pencemaran pada Sarana Air Sumur Gali Di Desa Pal IX Kecamatan Sungai Kakap

\begin{tabular}{|c|c|c|c|c|c|c|}
\hline \multirow{2}{*}{ No. } & \multirow{2}{*}{ Titik Sampel } & \multirow{2}{*}{ Skor Risiko } & \multicolumn{4}{|c|}{ Tingkat Risiko Pencemaran } \\
\hline & & & Rendah & Sedang & Tinggi & Amat Tinggi \\
\hline 1. & Sumur Gali 1 & 7 & & & $\sqrt{ }$ & \\
\hline 2. & Sumur Gali 2 & 7 & & & $\sqrt{ }$ & \\
\hline 3. & Sumur Gali 3 & 8 & & & $\sqrt{ }$ & \\
\hline 4. & Sumur Gali 4 & 6 & & & $\sqrt{ }$ & \\
\hline 5. & Sumur Gali 5 & 8 & & & $\sqrt{ }$ & \\
\hline 6. & Sumur Gali 6 & 2 & $\sqrt{ }$ & & & \\
\hline 7. & Sumur Gali 7 & 8 & & & $\sqrt{ }$ & \\
\hline 8. & Sumur Gali 8 & 8 & & & $\sqrt{ }$ & \\
\hline 9. & Sumur Gali 9 & 7 & & & $\sqrt{ }$ & \\
\hline 10. & Sumur Gali 10 & 3 & & $\sqrt{ }$ & & \\
\hline
\end{tabular}

Sumber: Hasil Analisis, 2021 
Kemudian untuk sumur gali dengan tingkat risiko pencemaran rendah, sumur gali tidak memiliki saluran air untuk mengalirkan air yang terdapat dipermukaan sekitar sumur gali. Lantai semen disekitar sumur gali yang pada tingkat risiko pencemaran rendah perlu ditinggikan $20 \mathrm{~cm}$ diatas permukaan tanah sesuai SNI 03-2916-1992 Spesifikasi Sumur Gali untuk Air Bersih. Oleh karena itu, pemilik sarana sumur gali perlu melakukan pemeliharaan terhadap lingkungan sekitar dan kondisi fisik sumur gali yang digunakan untuk menghindari terkontaminasinya air sumur oleh bakteri Coliform (Hadi dkk, 2014).

Pemilik sarana sumur gali dengan tingkat risiko pencemaran yang tinggi sebaiknya melakukan pemeriksaan terhadap air sumur serta perbaikan mutu kualitas air dengan melakukan desinfeksi pada air sumur gali. Proses desinfeksi dilakukan untuk meyisihkan kandungan bakteri Coliform yang terdapat di dalam air sumur gali (Puti, 2017). Sebaiknya pembangunan sarana sumur gali di Desa Pal IX oleh masyarakat harus sesuai dengan SNI 03-2916-1992 Spesifikasi Sumur Gali untuk Air Bersih untuk meminimalisir tingkat risiko pencemaran terhadap kualitas air sumur gali.

\section{Kesimpulan}

Berdasarkan penelitian yang telah dilakukan dapat disimpulkan bahwa sebanyak 8 sampel tidak memenuhi syarat jumlah Coliform, terdapat hubungan antara konstruksi sumur (dinding, bibir, lantai) dan sanitasi lingkungan gali (septic tank, tempat pembuangan sampah) terhadap kandungan bakteri Coliform dalam air sumur gali. Namun tidak terdapat hubungan secara statistik antara saluran pembuangan air limbah (SPAL) terhadap kandungan bakteri Coliform dalam air sumur gali. Secara keseluruhan tidak ada sumur gali yang memenuhi persyaratan berdasarkan variabel pengamatan yaitu parameter bakteriologis dan kondisi lingkungan yang terdapat di Desa Pal IX Kecamatan Sungai Kakap Kabupaten Kubu Raya.

\section{Daftar Pustaka}

Achmad, Bromo. (2020). Hubungan Sitem Pengelolaan Air Limbah Tangki Septik Dengan Kandungan Escherichia coli terhadap Kualitas Air Sumur Gali. Jurnal Keperawatan dan Kesehatan Masyarakat. 9 (I), 24-36.

Alya, N., Mursid, R., \& Nikie, A. (2018). Gambaran Kualitas Bakteriologis Air Sumur Gali Di Wilayah Kerja Puskesmas Pengasih 1. Jurnal Kesehatan Masyarakat, 6 (6), 8-16.
Angela, Suryani \& Woodford B.S (2012). Gambaran Kondisi Fisik Sumur Gali Ditinjau Dari Aspek Kesehatan Lingkungan dan Perilaku Pengguna Sumur Gali Di Kelurahan Sumompo Kecamatan Tuminting Kota Manado. Jurnal Kesehatan Masyarakat, 1 (1), 28-35.

Badan Pusat Statistik Kabupaten Kubu Raya. 2020. Kecamatan Sungai Kakap dalam Angka 2020.

Dayani, Sangadjisowohy. (2019). Uji Kandungan Bakteriologi pada Air Sumur Gali Ditinjau dari Konstruksi Sumur Di kelurahan Sangaji Kecamatan Ternater Utara. Jurnal Kesehatan Masyarakat, 9 (1). 20-27.

Departemen Kesehatan RI. 2007. Direktorat Jendral Pengendalian Penyakit dan Penyehatan Lingkungan. Direktorat Penyehatan Lingkungan 2007.

Dinas Kesehatan Kabupaten Kubu Raya. 2019. Data 10 Besar Riwayat Penyakit di Wilayah Kerja Puskesmas Kecamatan Sungai Kakap. Kubu Raya: Dinas Kesehatan Kabupaten Kubu Raya 2020.

Dita, Ade. (2021). Hubungan Sistem Pembuangan Limbah Rumah Tangga Dan Kontruksi Sumur Gali Dengan Kualitas Fisik Air Di Wilayah Kerja Puskesmas Salo. Jurnal Kesehatan Masyarakat, 5 (1), 228-235.

Dwi, A., Sarmono. (2021). Gambaran Kualitas Bakteriologis Air Sumur Gali Di Desa Karanganyar Kecamatan Purwanegara Kabupaten Banjarnegara. Jurnal Medsains, 7(1), 11-18.

Erlan, S., Taufik, A., \& Majdi, M. (2020). Analisis Hubungan Konstruksi Sumur Gali dan Sanitasi Lingkungan Terhadap Jumlah Bakteri Coliform Dalam Air Sumur Gali. Jurnal Teknik Lingkungan, 6 (2), 129-135.

Fralen, J., Finny, W., \& Rahayu, H. (2021). Identifikasi Kandungan Escherichia Coli Air Sumur Gali Dan Konstruksi Sumur Di Desa Poopoh Kecamatan Tombariri. Jurnal Kesehatan Masyarakat, 10 (6), 124-133.

Hadi, Sumardi dan Widyastuti. (2014). Pengelolaan Sumberdaya Air Terpadu. Yogyakarta: Gajah Mada University Press.

Hanan, L., Yudhy., D. (2020). Analisis Spasial Kejadian Diare dengan Keberadaan Sumur Gali di Kelurahan Jabungan Kota Semarang. Jurnal Kesehatan Lingkungan Indonesia, 19 (1), 6875.

Herninda, T., \& Sudarno. (2016). Pengaruh Sistem Pengelolaan Air Limbah Domestik Terhadap Kualitas Air Sumur Ditinjau Dari Konsentrasi TDS, Klorida, Nitrat. COD dan Total Coliform 
Pemukiman Tanjungsari Kelurahan Tembalang. Jurnal Teknik Lingkungan. 5 (1). 111.

Inayah, F \& Intan, F. (2018). Deteksi Cemaran Bakteri Escherichia Coli Pada Air Sumur Di Desa Kaligentong Kecamatan Pucanglaban Kota Tulungagung. Jurnal Prosiding Seminar Nasional Sains Teknologi dan Analisis, 1 (1), 88-93.

Lintje, Boekoesoe. (2010). Tingkat Kualitas Bakteriologis Air Bersih di desa Sosial Kecamatan Paguyaman kabupaten Baelemo. Jurnal Inovasi. 7 (4).

Nashiroh, Insani. 2017. Gambaran Karakteristik Sumur warga di Wilayah Kerja Puskesmas Kedungmundu Kota Semarang. Jurnal Kesehatan Masyarakat Universitas Diponegoro, $5(2), 48-52$.

Nurhadini. 2016. Studi Deskriptif Sumur Gali Ditinjau Dari Kondisi Fisik Lingkungan Dan Praktik Masyarakat Di Kabupaten Boyolali. Skripsi. Universitas Negeri Semarang: Semarang.

Peraturan Menteri Kesehatan Republik Indonesia No. 32 Tahun 2017 tentang Standar Baku Mutu Kesehatan Lingkungan dan Persyaratan Kesehatan Air Untuk Keperluan Higiene Sanitasi, Kolam Renang, Solus Per Aqua, dan Pemandian Umum.

Peraturan Menteri Kesehatan Republik Indonesia No. 416/MENKES/PER/IX/1990 tentang Syaratsyarat dan Pengawasan Kualitas Air.

Peraturan Pemerintah (PP) No. 82 Tahun 2001. Pengelolaan Kualitas Air Dan Pengendalian Pencemaran Air.

Puji, R., Tri, J., Hanan, J. (2019). Hubungan Faktor Risiko Pencemaran Sumur Gali Dengan Kualitas Bakteriologis Di Lingkungan Pemukiman RW IV Kelurahan Jabungan Kota Semarang. Jurnal Kesehatan Masyarakat, 7 (3), 156-163.

Puti, Komala. 2017. Inaktivasi Bakteri Escherichia coli Air Sumur Gali Menggunakan Desinfektan Kaporit. Jurnal Dampak Laboratorium Air Jurusan Teknik Lingkungan Universitas Andalas. 11 (1), 34-47.

Radjak, Nurmala Febriyanti. 2013. Pengaruh Jarak Septic Tank dan Kondisi Fisik Sumur Terhadap Keberadaan Bakteri Escherichia coli pada Sumur Gali. Universitas Negeri Gorontalo: Gorontalo.

Sabanari, Gita. 2018. Uji Bakteriologis Air Sumur Gali Ditinjau Dari Faktor Konstruksi Dan Sanitasi
Lingkungan Sekitar Sumur Di Kelurahan Makawidey Kecamatan Aertembaga Kota Bitung. Jurnal Kesehatan Masyarakat, 7 (4).

Sapulete, Margareth. 2010. Hubungan Antara Jarak Septic Tank Ke Sumur Gali Dan Kandungan Escherichia Coli Dalam Air Sumur Gali Di Kelurahan Tuminting Kecamatan Tuminting Kota Manado. Fakultas Kedokteran Universitas Sam Ratulangi: Manado.

Standar Nasional Indonesia (SNI) 03-2916-2992 tentang Spesifikasi Sumur Gali Untuk Air Bersih.

Standar Nasional Indonesia (SNI) 01-2332.1-2006 tentang Cara Uji Mikrobiologi.

Stiffany, Clara. 2018. Kandungan Escherichia coli Pada Air Sumur Gali Dan Jarak Sumur Dengan Septic Tank Di Kelurahan Rap-Rap Kabupaten Minahasa Utara Tahun 2018. Jurnal Kesehatan Masyarakat. 7 (4), 1-6.

Sumantri. 2010. Kesehatan Lingkungan. Kencana Prenada Media Group: Jakarta

Tattit, Khomariyatika. 2011. Faktor Yang Berhubungan Dengan Kualitas Bakteriologis Air Sumur Gali. Jurnal Ilmu Kesehatan Masyarakat, 11 (1), 20 28.

Ulwia. (2019). Pemeriksaan Kualitas Air Secara Bakteri Colitinja Dan Kandungan Mpn Coliform Pada Air Sumur Gali Di RT 02/RW 01 Desa Poka Kecamatan Teluk Ambon. Jurnal Global Health Science, 4 (3), 178-181.

WHO (World Health Organization). 2013. Diarrhoeal Disease. [Online]. Avaible at: http://www.who.int/mediacentre/factsheets/f s330/en/ [Diakses Januari 2021].

Wibowo, Ari. (2013). Penyuluhan Sumur Resapan Dan Sanitasi Untuk Edukasi Lingkungan Sehat Sesuai Standar Kesehatan Pada Masyarakat. Jurnal Inovasi dan Kewirausahaan, 2 (1), 41-50.

Yuniarti, D., Koosdaryani., \& Sulastoro. (2015). Analisis Konstruksi Sumur Yang Mempengaruhi Munculnya Bakteri Coli Pada Kecamatan Pasar Kliwon Kota Surakarta. Jurnal Matriks Teknik Sipil, 5(3), 81-88.

Zulfikar., Ratina, P., \& Wiwit, A. (2019). Hubungan Risiko Tercemar Sumur Galidengan Keberadaan Bakteri Escherichia coli di Gampong Daroy Kameu. Jurnal Kesehatan Lingkungan, 11 (2), 5664. 